\title{
Chromosome abnormalities in neuroblastoma
}

\author{
D. J. BREWSTER ${ }^{1}$ AND J. V. GARRETT ${ }^{2}$ \\ From Selly Oak Hospital, Birmingham
}

SYNOPSIS The case is briefly reported of a 7-month-old boy with a disseminated neuroblastoma, whose marrow showed neuroblastoma rosettes and on direct examination on two occasions revealed a high proportion of cells with 48 chromosomes forming an abnormal cell line.

Neuroblastoma, retinoblastoma, and medulloblastoma are examples of malignant tumours usually occurring in infancy or early childhood and arising from rudiments of organs or tissues which are still immature. As such, they raise the question as to whether their pathogenesis is the same as that of malignant tumours arising in adults.

We have had the opportunity of examining the chromosomes of mitotic cells in the bone marrow of a young child with disseminated neuroblastoma and the following is a short account of our findings.

\section{CASE HISTORY}

The child, a negro boy, was born in Britain on 14 December 1961, the third child of apparently normal West Indian parents. He has two normal brothers, aged 5 and 3 years. During the pregnancy the mother had developed mild diabetes and had a chest radiograph taken in the fifth month.

At birth the boy appeared normal and weighed $3.95 \mathrm{~kg}$. At 4 months old he developed an illness considered to be pertussis and was admitted to another hospital for one month. He then returned home but later developed vomiting and distension of the abdomen and was admitted to Selly Oak hospital in July 1962.

On admission he was found to be severely ill with anaemia and gross enlargement of the liver and spleen. Blood examination showed: haemoglobin $5.5 \mathrm{~g} . / 100 \mathrm{ml}$. (37\%); white blood cells 33,400 per c.mm.; (polymorphs $27 \%$, lymphocytes $47 \%$, monocytes $8 \%$, abnormal neoplastic cells $18 \%$ ). A tibial marrow puncture in July 1962 revealed infiltration by tumour cells, some in clumps and some showing the characteristic rosette pattern typical of neuroblastoma (Fig. 1). This finding was confirmed by a second marrow examination three months later and subsequent marrow examinations showed numerous similar tumour cells.

${ }^{1}$ Present address: Department of Anatomy, Medical School, University of Birmingham.

${ }^{2}$ Present address: Department of Pathology, Christie Hospital, Manchester 20.

Received for publication 23 June 1964.

5
The diagnosis of neuroblastoma was also confirmed by the demonstration in the urine of abnormally large amounts of 4-hydroxy-3-methoxy mandelic acid and 3-hydroxy-tryamine, metabolic products of adrenalin and noradrenalin which have been reported as characteristic of neuroblastoma (Voorhess and Gardner, 1960).

The patient was treated by blood transfusion, cyclophosphamide, methotrexate, and vitamin $\mathbf{B}_{12}$ with marked improvement, including reduction in size of the liver and spleen.

Marrow aspirated from the left iliac crest on 15 May 1963 showed great hypercellularity with $60 \%$ abnormal

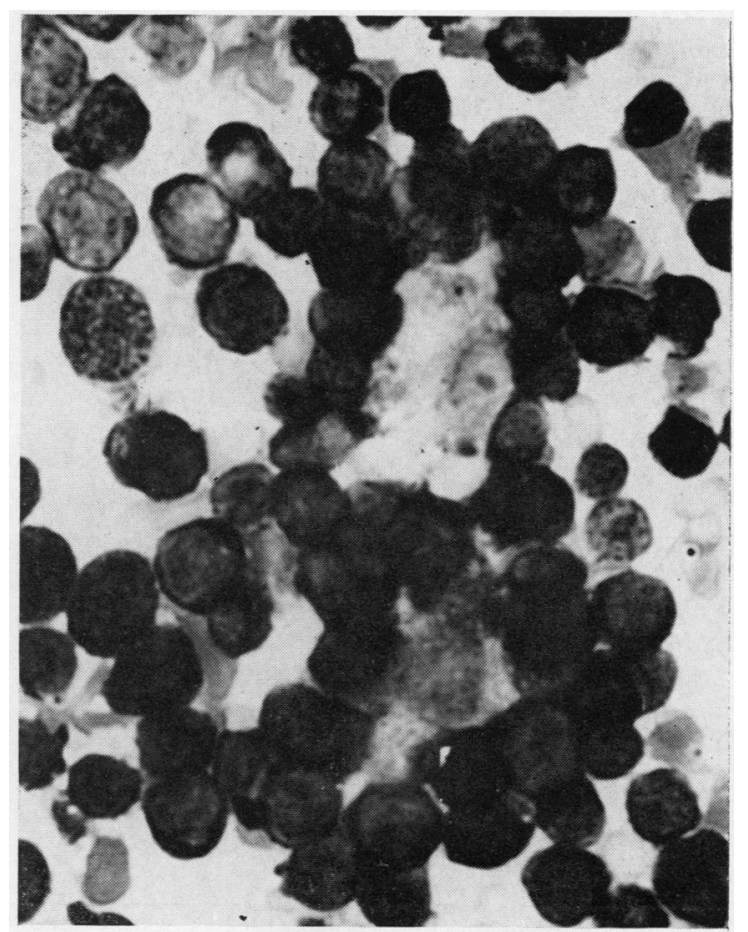

FIG. 1. Neuroblastoma rosette in marrow film. $\times 450$. 
cells. Chromosome studies were performed on this specimen. A relapse shortly after this was controlled by intravenous cyclophosphamide but a further deterioration occurred at the end of October 1963. On 1 November 1963 a tibial marrow examination was done four days after chemotherapy had been temporarily discontinued and showed similar findings to the previous one. Chromosome studies were also performed on this specimen.

A further remission was induced by intravenous cyclophosphamide in November 1963 and continued up to March 1964.

This child died in August 1964 with anaemia and leucopenia, which did not respond to treatment.

At necropsy the marrow was found to be practically entirely replaced by tumour tissue which was also present in lymph nodes and the spleen, but no other primary site was found. The histological appearances of the tumour were considered consistent with neuroblastoma of rather undifferentiated type, but with occasional cells showing some degree of differentiation.

\section{RESULTS OF CHROMOSOME STUDIES}

Portions of the marrow aspiration specimens obtained on 15 May 1963 and 1 November 1963 were processed for chromosomal analysis by a slight modification of the method of Tjio and Whang (1962). A high proportion of the cells were observed to be in mitosis and were most probably neuroblastoma cells.

The results of the chromosome studies are summarized below.

Chromosomal analysis of the first specimen showed that $26(37 \%)$ of the cells had 48 chromosomes with an extra medium-sized submetacentric (group 6-12, Denver classification) and an extra small submetacentric (group 16-18). Three other cells with 48 chromosomes had two extra chromosomes in group 6-12. Of the cells with 47 chromosomes, eight had one extra in group 6-12 and two had one extra in group 16-18, in addition to the normal complement. Nine of the cells with 46 chromosomes appeared to have a normal karyotype. The others showed inconstant abnormalities.

In a similar analysis of the second specimen 54 cells $(77 \%)$ were seen to have 48 chromosomes with one extra in each of the groups 6-12 and 16-18 (Fig. 2). Three of the cells with 47 chromosomes possessed the two extra chromosomes characteristic of the 48-chromosome cell line but had one other chromosome, a different one in each case, missing. Of the seven remaining cells with 47 chromosomes, three had an extra chromosome in group 6-12 and four an extra one in group 16-18. Two of the cells

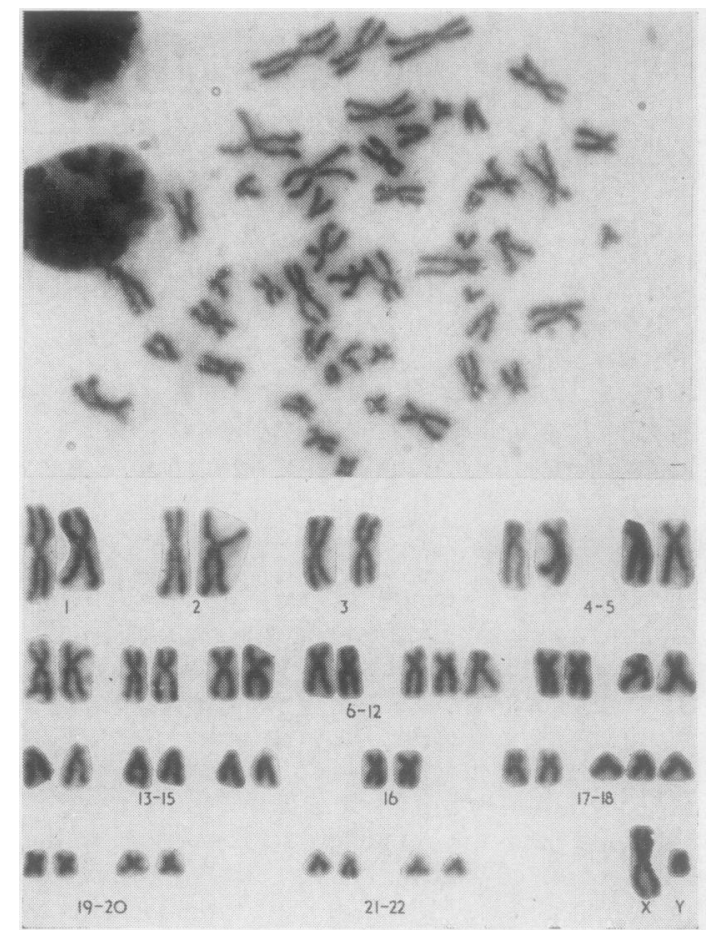

FIG. 2. Mitotic cell from marrow and karotype showing two extra chromosomes which are tentatively placed next to chromosomes 10 and $18 . \times 1,000$.

with 46 chromosomes had a normal karyotype. The other two were abnormal but one of these had the extra chromosomes seen in the 48-chromosome cell line.

It is of interest that the patient's peripheral leucocytes, which were cultured and processed on three occasions by the usual method (Moorhead, Nowell, Mellman, Battips, and Hungerford, 1960), did not show any chromosomal aberrations. Cultures of the leucocytes of both parents also gave normal results.

\section{DISCUSSION}

These results suggest that an abnormal population of cells with 48 chromosomes had appeared in the marrow when the first sample was taken and had become dominant by the time the second specimen was taken.

The literature contains many references to chromosome abnormalities in tumours but usually

\begin{tabular}{|c|c|c|c|c|c|c|c|c|c|c|}
\hline Date & No. of Chromosomes & $<44$ & 44 & 45 & 46 & 47 & 48 & 49 & Polyploid & Total \\
\hline $\begin{array}{l}15.5 .63 \\
1.11 .63\end{array}$ & $\begin{array}{l}\text { No. of cells } \\
\text { No. of cells }\end{array}$ & $\begin{array}{l}8 \\
2\end{array}$ & $\begin{array}{r}3 \\
-\end{array}$ & $\underline{2}$ & $\begin{array}{r}12 \\
4\end{array}$ & $\begin{array}{l}10 \\
10\end{array}$ & $\begin{array}{l}30 \\
54\end{array}$ & $\underline{3}$ & 2 & $\begin{array}{l}70 \\
70\end{array}$ \\
\hline
\end{tabular}


these appear to have been inconstant. With the introduction of new techniques, however, the appearance of abnormal cell lines, as shown by consistent chromosome abnormalities, has been described in a number of cases of malignancy. The congenital tumours form a particularly interesting group to study and a number of reports have appeared in the literature. So far as neuroblastoma is concerned, the previously reported cases do not appear to have had chromosome abnormalities of the type described above. Thus Gagnon, Dupal, and Katyk-Longtin (1962) investigated a case of undifferentiated neuroblastoma invading the liver of a newborn girl and found a modal chromosome number of 48 with two abnormally large acrocentric chromosomes in addition to the normal complement in cultures from a liver biopsy. Spriggs, Boddington, and Clarke (1962), in an investigation of the chromosomes of various tumours, found abnormal karyotypes with modes of 46 and 92 in cells in a pleural effusion from a 3-year-old girl with neuroblastoma.

Similarly, no consistent aberrations have been found in retinoblastoma. Lele, Penrose, and Stallard (1963) reported a deletion of part of a chromosome in group 13-15 in cultures of several tissues of one case but five other cases did not show any anomaly. Wiener, Reese, and Hyman (1963) found a normal chromosomal constitution in the peripheral leucocytes of 17 patients with a present or past history of retinoblastoma. Day, Wright, Koons, and Quigley (1963), in an investigation of a patient with Down's syndrome and a history of retinoblastoma, reported finding an XXX sexchromosome constitution and 21-trisomy, but no other consistent aberrations, in cultured lymphocytes.

The changes described in the present case, with the production of an abnormal cell line, are more like those described in acute leukaemia by Baikie, Jacobs, McBride, and Tough (1961) than those reported in tumours.

We are indebted to Dr. H. McC. Giles for permitting us to study his patient, to Dr. C. E. Ford for advice, and to the Birmingham Regional Hospital Board for financial assistance from their research funds.

\section{REFERENCES}

Baikie, A. G., Jacobs, P. A., McBride, J. A., and Tough, I. M. (1961). Brit. med. J., 1, 1564.

Day, R. W., Wright, S. W., Koons, A., and Quigley, M. (1963). Lancet, 2, 154.

Gagnon, J., Dupal, M. F., and Katyk-Longtin, N. (1962). Rev. Canad. Biol., 21, 145.

Lele, K. P., Penrose, L. S., and Stallard, H. B. (1963). Ann. hum. Gen., 27, 171.

Moorhead, P. S., Nowell, P. C., Mellman, W. J., Battips, D. M., and Hungerford, D. A. (1960). Exp. Cell Res., 20, 613.

Spriggs, A. I., Boddington, M. M., and Clarke, C. M. (1962). Brit. med. J., 2, 1431 .

Tjio, J. H., and Whang, J. (1962). Stain Technol., 37, 17.

Voorhess, M. L., and Gardner, L. I. (1960). Lancet, 2, 651

Wiener, S., Reese, A. B., and Hyman, G. A. (1963). Arch. Ophthal., 69, 311. 